\title{
The Research on Teaching Reform of the Social Security Courses
}

\author{
Zhang Yanli $^{1}$ \\ ${ }^{1}$ School of public management, Shandong Technology and Business University, Yantai, Shandong 264005, China \\ *Corresponding author. Email: yanlizh6565@163.com
}

\begin{abstract}
There are many problems in the teaching of social security courses, such as the teaching difficulties of the subject, the restriction of the textbooks and the courses time, the restriction of the experiment and the practice conditions, the traditional teaching mode of filling, the general lack of the speculative ability of the college students. In order to meet the requirements of practical talents cultivation, it is necessary to improve experiment and practice conditions and teaching and practical level of the social security subject in colleges and universities from the aspects of laboratory and practice base construction, teacher training, teaching content design and teaching methods.
\end{abstract}

Keywords: practical talents cultivation, social security courses, teaching reform

\section{Introduction}

The subject of social security is a comprehensive and intersecting subject. By the end of 2017, there are 179 colleges and universities that could recruit undergraduates majoring in labour and social security. There are about 100 colleges had set up social security departments, with an annual enrolment scale of nearly 10,000. [1] Every year, the social security specialty conveys a large number of professionals to the social security management and service field of government agencies and enterprises and institutions in China. In recent years, with the adjustment and perfection of social security policies and regulations in China and the continuous enhancement of people's social security consciousness and demand, these put forward higher requirements for the cultivation of practical talents of social security specialty in colleges and universities. However, there are some crises and challenges in the teaching of social security specialty.

\section{THE CRISES AND CHALLENGES IN THE TEACHING OF SOCIAL SECURITY SPECIALTY}

\subsection{The Teaching Difficulties of Social Security Subject}

Social security subject is with strong applicability, strong policy relevance and strong dynamics.[2] Since 1990s, China has implemented a number of social security policies reforms. For example, since January 1, 2019, the tax department has collected all kinds of social insurance premiums uniformly in China. Since May 1, 2019, China has implemented the Comprehensive Plan for reducing Social Insurance rates. Every year, social security, in other words, livelihood issues is a hot topic of public opinion to the representatives of the Chinese Representatives of People's Congress and Political Consultative Conference. All these require teachers to adjust the teaching content and teaching scheme design of social security specialty in time according to the latest reforms of social security policies.

\subsection{The Restriction of the Textbooks and the Courses Time}

At present the textbooks of social security specialty on the market are mainly focused on 'Introduction to Social Security' or 'The Theory of Social Security'. There are also a few textbooks, such as 'Social Insurance', 'Social Assistance', 'Social Welfare' or 'Social Security Funds' and so on. On the one hand, however, the main problem with these textbooks is that most of them have not been updated in time in accordance with the latest reforms in social security policies. On the other hand, there are few specialized textbooks such as 'Pension', 'Medical Insurance', 'Employment Injury Insurance', 'Unemployment Insurance', and 'Enterprise Annuity'. In addition, professional experimental, practical teaching materials and professional foreign language teaching materials are very few. These problems in teaching materials have affected the curriculum setting of social security major in colleges and universities. In addition, some colleges and universities have fewer hours of social security courses, which cannot take into account the requirements of theoretical teaching, experiment and practical teaching. 


\subsection{The Restriction of the Experiment and the Practice Conditions}

At present, while the majority of colleges and universities continue to improve the hardware teaching facilities, more and more attention is paid to the cultivation of college students' practical ability. However, there are the following limitations in the experimental conditions: firstly, there are few colleges and universities equipped with social security laboratory. The construction of social security laboratory needs a lot of money. But many non-double first-class colleges and universities do not have sufficient financial support. Secondly, as mentioned above, there are few experimental and practical teaching materials for social security specialty, which affects the establishment of social security experiment and practice courses. The main reason for the lack of social security experiment and practice teaching materials is that most of the teachers majoring in social security directly teaching in colleges and universities after graduating from master's degree or doctor's degree. They are mainly engaged in social security theory research, but lack of social security practical work experience. As a result, few colleges' teachers could compile the Social Security Experiment textbook. Thirdly, more importantly, colleges and universities with existing social security laboratories generally do not have suitable experimental software. Because software companies generally lack the professional knowledge of social security, and the teachers of social security specialty in colleges and universities lack the ability of software development. This leads to the idle laboratories in many colleges and universities because they do not have the right software.

Although in the aspect of practical teaching, many colleges and universities have set up practical teaching bases. However, because the location of practical teaching base is far from colleges and universities, or there are too many students, or the government agencies and enterprises as practical teaching base cannot receive too many students frequently, otherwise their normal working order will be interfered with. There is a common phenomenon of low utilization rate of practical teaching base in colleges and universities.

\subsection{The Traditional Teaching Mode and the General Lack of the Speculative Ability of College Students}

The teachers have been actively talking and talking alone in class in the traditional teaching mode. And the students only passively accept the knowledge by eyes, ears and notes. And the teachers only pay attention to the teaching of knowledge points, but also pay attention to the rote memory of knowledge points. Before entering college, students from primary school to senior high school always accept the traditional teaching mode. During the college period, there were also mathematics, English and other indoctrination courses. Therefore, the traditional teaching mode is neither conducive to the cultivation of college students' thinking ability and the development of innovative and creative ability, nor conducive to the cultivation of students' practical talents. It is easy for students who have been adapted to this teaching method for a long time to think independently or question authority. This is the embodiment of the lack of rational speculative ability.

With the rapid development of Internet and information technology, Forums, Blogs, Podcasts, Weibo, Short Videos and other forms of self-media, human beings entered the era of Internet, Big Data and Self-media. However, a large number of complex information from the internet every day is full of worthless information, false information, and even fraudulent information and rumours. In addition, the long-term examination-oriented education and the traditional teaching mode make the college students in China generally lack the critical thinking and speculative ability, and they are difficult to distinguish the false things, retain the real things and distinguish right from wrong. Under the influence of Internet information technology and western culture, contemporary college students indulge in mobile games, short videos, movies or online communication and other forms of entertainment, lack of motivation to learn, but also reduce the ability of independent thinking and rational thinking. This greatly deviates from the original intention of the talent training mode in colleges and universities.

\subsection{The Disconnection between theoretical Learning and Practical Ability of College Students}

Document regulation is issued by the Ministry of Education in China that the specialty setting in colleges and universities is linked to the employment rate of graduates. Under this requirement, some colleges and universities of a few majors have stopped enrolments because of their low employment rate. From the national level, undergraduate education should not only train basic talents, but also cultivate practical applied talents. Only by transforming professional knowledge into productive forces through employment, so we contribute to national construction. However, at present, enterprises and institutions generally reach a consensus on the lack of practical experience and skills of fresh graduates. At present, college students rarely take the initiative to participate in social practice. A few students can take part 
in work-study activities or part-time activities in the process of study, but the correlation between these activities and their majors is low, which leads to the disconnection between theoretical learning and practical ability of college students. In addition, the long-term traditional infusion teaching method aggravates the disconnection between theoretical learning and practical ability of college students. There is no doubt that social practice is one of the important ways to improve the employability of college students. Therefore, the setting and teaching of professional courses in colleges and universities should abandon the boring theoretical propaganda of mechanical cramming and take into account the cultivation of theoretical learning and practical ability.

\section{BACKGROUND EXPLORATION OF TEACHING REFORM METHOD BASED ON PRACTICAL TALENT TRAINING}

To improve the training quality of students, it is necessary to improve the comprehensive quality of students. [3] With the change of the times, the popularization of Internet and IT, the mobile intelligent network terminal is widely used in the teaching reform mode based on the training of practical talents. However, contemporary college students are generally active in thinking, good at expression, and master the Internet and computer technology. Their ability to learn new things is strong, but their speculative ability and practical ability need to be improved. As the crisis and challenge faced by the teaching reform of social security specialty mentioned above, in order to meet the requirements of cultivating practical talents, I put forward the following suggestions on the teaching reform of social security specialty.

\subsection{The Construction of Laboratory and Practice Base}

Compared with the key universities, the general universities have a relatively single source of funds for teaching and training, but the number of students they train accounts for the majority of the graduates of colleges and universities in China every year. Therefore, the Ministry of Education in China should appropriately increase the special funds for the construction of laboratories in ordinary colleges and universities, in order to improve the quality of talents of college graduates in China. The social security specialty in colleges and universities should actively prepare for the construction of social security laboratory and provide hardware conditions for the training of practical social security professionals.
In the aspect of social security experimental software procurement, it is suggested that social security teachers in colleges and universities should participate in the procurement of social security experimental software, rather than fully purchasing the experimental software by executive staff. In order to increase the practicability and manoeuvrability of social security experimental software development, we should adopt problem orientation and strengthen the communication and negotiation between social security professional teachers and software companies, especially in compiling the details of software development requirements. In addition, increase the proportion of later development and debugging in total funds in the software procurement contract. So it is conductive to contribute the experimental software to improve the software with the adjustment of social security teaching content.

\subsection{The Aspect of Teacher Training}

The improvement of education quality is directly related to the quality of teachers. The discipline of Social Security is oriented to multidisciplinary practice. The Development orientation of the subject of Social Security requires all training units to strengthen the construction of teaching staff as soon as possible. [4]

Firstly, the government should attract and encourage the colleges' teachers majoring in social security to take parttime job at the social security practice base. That can also improve the social security practice and experimental ability of the teachers majoring in social security in colleges and universities at the same time.

Secondly, the government should attract and encourage the teachers of social security major in colleges and universities to compile textbooks such as 'Social Security experiment/practice', 'Management and Service of Pension', 'Management and Service of Medical Insurance', 'Management and Service of unemployment Insurance', 'Management and Service of Employment injury Insurance', 'Enterprise annuity' and so on, which not only improves the professional level of teachers, but also enriches the curriculum system of social security specialty. Thirdly, the government should try every means to balance the scientific research and teaching work of the university teachers. At present, the evaluation and performance appraisal of teachers in colleges and universities emphasize on scientific research very much, neglected the teaching work. However, the talent training is one of the most important teaching works in colleges and universities. Fourthly, the college should invite some experts from the corresponding social security practice base, such as government agencies and enterprises, to give lectures for students, and provide valuable practical experience for teachers and students of social security.

Fifthly, the colleges should regularly delegate some social security professionals to work at the government 
institutions, such as human resources and social security departments, to provide suggestions for the management and service for relevant departments, and also to improve the ability of the theoretical contact practice of the university teachers.

\subsection{The Aspect of Teaching Content Design and Teaching Method Reform}

Firstly, the teachers should explain the importance of mastering the theoretical knowledge and practical skills of social security for their vital interests through the introduction to the curriculum with the positive and negative practical cases. In modern society, we may suffer the social risks such as old age, disease, unemployment, disability and so on, so the government establishes the social security system to avoid these social risks for us. College graduates majoring in social security need to master the professional knowledge and practical skills of social security, whether they work in human resources and social security related professional work in enterprises and institutions, or protect their own social security rights and interests as ordinary citizens.

Secondly, in the design of teaching content, the teachers should combine social security practice cases to explain the theory knowledge, choose the latest and most representative social security reform events to form teaching cases, mobilize students' interest in learning, and improve students' speculative ability and the ability to solve practical problems by using social security theoretical knowledge.

Thirdly, the teachers should guide students to collect and analyse data, cultivate students' critical thinking and improve students' rational analysis ability. For example, 'should China extend the legal retirement age?' 'Should social insurance in China been changed from fees into taxes?' 'Should China's Social Security Fund invest in the market?' 'Pay-As-You-Go System, or fund pension insurance system can cope with the aging of the population?'

Fourthly, abandon the traditional indoctrination teaching method. In order to improve students' ability of expression and logic, the case discussion of classroom teaching is carried out. The teachers should use the interactive teaching mode based on critical thinking by replacing the simple knowledge with the inspiration and guidance of the problem, replacing the passive knowledge indoctrination with the active knowledge acquisition. The teachers should pay attention to the application of the basic theory of the teaching material in the social practice, aims at improving the students' speculative ability and critical thinking, expand the quality related to the professional core competence, so as to realize the docking between the professional teaching and the industry demand.

Fifthly, the teachers should combine the 'learning goal', 'teaching activity' and 'feedback and evaluation' in teaching activities through the construction of 'feedback mechanism'. During the teaching activities in each chapter of the textbook, teachers should select the classic 'teaching cases' on the basis of 'Learning Goals'. Make students to discuss 'teaching cases' in study groups in conjunction with what they have learned in this chapter. Make students to analyse and resolve issues relating to social security cases, and to allow debate. Finally, the teachers comment on the basis of the student discussion. [5] At the end of the case discussion, ask the students to fill in the questionnaire about 'the feedback and evaluation of teaching case'. The teacher revises the teaching case through the questionnaire.

\section{CONCLUSION}

In short, the classroom is the main position of colleges and universities. In order to improve the teaching effect and cultivate the practical talents of social security specialty needed by the state and society, the classroom is the main battlefield of colleges and universities. The teachers of colleges and universities and social security majors should improve the design of teaching links, arouse the enthusiasm of students, and improve experiment and practice conditions, teaching and practice level of social security majors in colleges and universities.

\section{ACKNOWLEDGMENT}

This work was supported by Shandong Technology and Business University Teaching Reform Project 'Research on Problem-oriented Inquiry Teaching Reform: a case study of Social Security Courses' (11688201716), Shandong Technology and Business University Doctor Funds Project (BS201807) and Ministry of Education Youth Fund Project (16YJC820033).

\section{REFERENCES}

[1] ZHENG Gongcheng, Review and Prospect of Social Security discipline Construction in China, People's Daily, 16th edition, August 13, 2018.

[2] WANG Hong, Survey of Teaching Reform on Social Security for Students Majoring in Human Resources Management, Journal of Sichuan College of Education, Vol.27. Oct.2011.pp.15-17, 27.

[3] LONG Yuqi, LIU Qiaohong, LIU Xinxin, On Professional Ideological Education in Teaching of Social Security Courses, Journal of Beijing Vocational College of Labour and Social Security, Vol.7.2013. NO.3.pp.59-61,66.

[4] Meng Yingying, Social Security: Challenges, Orientation and Development, in: Wuhan University Journal ( Philiosophy \& Social Sciences),Vol.66.No.1 Jan, 2013, pp. 052-056.

[5] GOU Xingchao, A Study of the Application of Case Teaching in the Social Insurance Courses, in: Journal of Leshan Normal University, Vol.28, No.11.Nov.2013, pp. 51-54. 